\title{
Potential health impact of ultrafine particles under clean and polluted urban atmospheric conditions: a model-based study
}

\author{
Leila Droprinchinski Martins • Jorge A. Martins • Edmilson D. Freitas • \\ Caroline R. Mazzoli • Fabio Luiz T. Gonçalves • Rita Y. Ynoue • Ricardo Hallak • \\ Taciana Toledo A. Albuquerque $\cdot$ Maria de Fatima Andrade
}

Received: 17 December 2008 / Accepted: 17 June 2009 / Published online: 4 August 2009

(C) The Author(s) 2009. This article is published with open access at Springerlink.com

\begin{abstract}
The main goal of this study was to improve the knowledge of ultrafine particle number distributions in large urban areas and also to call the attention to the importance of these particles on assessing health risks. Measurements of aerosol size distributions were performed during 2 weeks, with distinct pollutant concentrations (polluted and clean periods), on the rooftop of a building located in downtown of the megacity of São Paulo, Brazil. $\mathrm{CO}, \mathrm{NO}_{2}, \mathrm{PM}_{10}, \mathrm{SO}_{2}$, and $\mathrm{O}_{3}$ concentrations and meteorological variables were also used. Aerosol size distribution measurements showed that geometric mean diameters of the size spectra in the polluted period are on average considerably larger than those in the clean one. Besides the fact that total number of ultrafine particles did not show significant differences, during the polluted period, geometric mean diameter was larger than during the clean one. The results of a mathematical model of particle deposition on human respiratory tract indicated a more significant effect of smaller particles fraction of the spectra, which predominate under clean atmospheric conditions. The results also indicated that urban environmental conditions usually considered good for air quality, under the criteria of low mass concentration, do not properly serve as air quality
\end{abstract}

L. D. Martins $(\bowtie) \cdot$ E. D. Freitas $\cdot$ C. R. Mazzoli

F. L. T. Gonçalves • R. Y. Ynoue • R. Hallak •

T. T. A. Albuquerque $\cdot$ M. de F. Andrade

Department of Atmospheric Sciences, Institute of Astronomy, Geophysics and Atmospheric Sciences, University of São Paulo, Rua do Matão, 1226,

São Paulo 05508-900 São Paulo, Brazil

e-mail: leiladro@model.iag.usp.br

\section{J. A. Martins}

Department of Environmental Engineering,

Federal University of Technology,

Londrina 86020-430 Paraná, Brazil standard to very small particles. In the size range of ultrafine particles, this traditional clean atmospheric condition can offer a strong risk to pulmonary hazards, since the cleansing of the atmosphere creates good conditions to increase the concentration of nucleation mode particles.

Keywords Aerosol size distribution $\cdot$ Health impacts $\cdot$ Model of particle deposition - Ultra fine particles · Air quality

\section{Introduction}

It has been known that particulate matter (PM), a mixture of solid particles and liquid droplets found in the air, causes a number of health effects. Exposure to elevated levels of PM increases the rate of respiratory problems, hospitalizations due to lung or heart disease, and premature death (Holberg et al. 1987; Asgharian et al. 2001a, b). Fuel combustion, industries, and power plants are the main sources of particles in urban and industrialized areas (Zhang et al. 2007). In the context of air quality standards established in pollution regulation, PM essentially involves the mass of suspended particles. For example, $\mathrm{PM}_{10}$ concentration refers to the mass of particulate material smaller than $10 \mu \mathrm{m}$ in size. The exposure to high concentration of engine exhaust emission in urban atmosphere has only occurred in recent human history and lungs have not become adapted to functioning under a high exposure to pollutants. In addition, recent studies suggest that the population has been exposed to health risks in levels well below those allowed by the current air quality standard (US-EPA 2007; Baldauf et al. 2009). Thus, the $\mathrm{PM}_{10}$ or even $\mathrm{PM}_{2.5}$ concentrations alone may not be determinant factors for the toxicity of particles. Parameters describing the size distribution, the total surface area, the time- 
dependent dissolution, and the physical, chemical, and biological properties may also be important. Depending upon the atmospheric conditions, the health risks can be aggravated (Cheng et al. 2009).

Recently, ultrafine particles (UFP), those with an aerodynamic diameter less than $100 \mathrm{~nm}$, have been highlighted with more frequency in scientific studies since they have been considered a factor contributing to a series of health problems, including premature death, aggravated asthma, chronic bronchitis, and a number of social consequences (e.g., Oberdörster et al. 2005a, b; Sioutas et al. 2005; Asgharian and Price 2007). Toxic effects have already been documented in pulmonary, cardiac, reproductive, renal, cutaneous, and cellular levels (Ostiguy et al. 2006). UFP in the air have a high mobility and can enter into the human body through the inhalation route. Despite having some defense mechanisms, the alveolar tissue is not as well protected against environmental damages as the skin and gastrointestinal tract are and is therefore the most vulnerable contact site (Biswas and $\mathrm{Wu}$ 2005). The large number concentration of UFP decreases the alveolar macrophage ability of eliminating foreign particles (Donaldson et al. 2001; Biswas and Wu 2005). This causes an increase in exposure time between particles and lung epithelial cells and also a strong size-selective difference in particle immobilization (Semmler-Behnke et al. 2007). The small size of particles also contributes to the transcytosis across epithelial and endothelial cells into the blood and lymph circulation, reaching potentially sensitive target sites such as bone marrow, lymph nodes, spleen, and heart. Access to the central nervous system and ganglia via translocation along axons and dendrites of neurons has also been observed (Oberdörster et al. 2005a, b).

Exhaust emissions may change significantly as a consequence of motor and fuel modifications (see Ristovski et al. 2006; Frank et al. 2007). With changes in engine exhaust properties, there is a need to further understand the emitted particles, since most changes are carried out in order to improve both air quality and health conditions. Particularly in the Metropolitan Area of São Paulo (MASP), Brazil, studies concerning engine exhaust properties are urgent, and only a few studies have been performed in order to assess the role of vehicular emission on observed pollution levels (Ynoue and Andrade 2004; Martins et al. 2006). The vehicle fleet in Brazil is unique in the sense that ethanol is used as fuel on a large scale. Part of the light-duty fleet runs on hydrated ethanol $(95 \% v / v)$ and another part runs on a mixture containing $75-78 \%$ gasoline and $22-$ $25 \%$ anhydrous ethanol, which is referred as gasohol. Flex-fuel vehicles (running on either gasohol or ethanol) and vehicles converted to burn compressed natural gas were recently introduced in the fleet, making it difficult to evaluate what kind of fuel is currently being burned.
According to the Brazilian National Petrol Agency (ANP; http://www.anp.gov.br, July 2008), ethanol accounts for more than $50 \%$ of the fuel burned by the light-duty fleet in the MASP.

In order to investigate the issues concerning the health effects of UFP and aerosol size distributions in the MASP, a study of a transition period between a highly polluted condition and a clean one in the MASP was conducted. Aerosol size distributions were recorded during a 2-week period between August and September 2003, during the winter season. Winter is usually characterized by an increase not only in respiratory and cardiovascular diseases, but also in morbidity and mortality rates in the MASP (Conceição et al. 2001; Farhat et al. 2005). Simultaneously, ambient pollutants and meteorological conditions were monitored near the site of measurements. Relationships among air quality, aerosol size distribution, and meteorological condition were investigated using data and numerical results. The relationship between the modeled UFP pulmonary deposition and overall pollutant levels was used in order to identify the necessity of reviewing pollution regulation and also to draw the attention of the scientific community to the lack of data and studies concerning this subject in Latin America.

Results concerning to the first measurements involving diurnal variation of the aerosol number size distribution $(9.82-414 \mathrm{~nm})$ in the highly polluted megacity of São Paulo are presented in this paper.

\section{Methodology}

The relationship between potential health effects and aerosol size distribution was investigated by combining field measurements of particle size distributions and numerical modeling. Air quality data were obtained from the Environmental Protection Agency of São Paulo State (CETESB). The CETESB network is comprised of 20 monitoring sites in the MASP. The five nearest air quality stations to the experimental location were selected to provide additional data related to particulate pollutants. Hourly averages of $\mathrm{PM}_{10}, \mathrm{SO}_{2}, \mathrm{NO}_{2}, \mathrm{CO}$, and $\mathrm{O}_{3}$ concentrations were used, starting on August 18 and extending up to September 2, 2003. Meteorological data concerning temperature, relative humidity, wind speed, and atmospheric pressure were also obtained from the same air quality stations (CETESB 2004).

Samplings of aerosol size distributions were carried out during the above-mentioned period. The measurements were performed on the rooftop of a building (approximately $14 \mathrm{~m}$ high) in the downtown of the city of São Paulo at $23.55^{\circ} \mathrm{S}$ and $46.63^{\circ} \mathrm{W}$. A scanning mobility particle sizer was employed to determine the size number distribution of 
submicron particles. The system measures the size distribution of aerosols by using an electrical mobility detection technique. Particles are classified with an Electrostatic Classifier (Model TSI $3080 \mathrm{~N}$ ), and their concentration is measured with a condensation particle counter. Scanning involves particles from 9.82 to $414 \mathrm{~nm}$, covering a total of 105 size channels in equal steps of logarithmic diameter. Data used in our calculations are based on hourly averages in agreement with the overall pollution data monitored in the MASP. Limits proposed by Laakso et al. (2003) were used for classifying particles size distribution, except for the upper limit which in this case was $414 \mathrm{~nm}$. Therefore, the nucleation mode was chosen to be 10-25 nm, Aitken mode $25-90 \mathrm{~nm}$, and accumulation mode $90-414 \mathrm{~nm}$ in particle diameter.

Mathematical models have been applied to describe respiratory deposition, clearance, and retention of aerosols (ICRP 2006; James et al. 1994; Hofmann et al. 2002; Asgharian et al. 2006; Choi and Kim 2007; Nazridoust and Asgharian 2008). In this study, the numerical modeling was based on the multiple path particle dosimetry model (MPPD). The MPPD is a computational model that can be used for estimating human and rat airway particle dosimetry (Anjilvel and Asgharian 1995; Freijer et al. 1999; Asgharian et al. 2001a, b; Price et al. 2002; Winter-Sorkina and Cassee 2002). According to Price et al. (2002), this model calculates the deposition and clearance of monodispersed and polydispersed aerosols in the respiratory tracts of rats, human adults, and children (deposition only) for particles ranging from ultrafine $(0.01 \mu \mathrm{m})$ to coarse $(10 \mu \mathrm{m})$ in size. The MPPD was applied to calculate the fraction of particles deposited and retained in specific parts of the human lung by comparing two different human exposure scenarios in the MASP. The first scenario was characterized by a highly polluted week, exceeding the National Ambient Air Quality Standards (NAAQS) for $\mathrm{PM}_{10}$ and also for other monitored pollutants. The second scenario was during the following week, with very low concentrations of predominant pollutants, not exceeding the NAAQS.

The MPPD model calculations were performed using default values for breathing. Nasal breathing scenario was assumed with equal breathing time during inhalation and exhalation. The breathing frequency and tidal volume were $12.0 \mathrm{~min}^{-1}$ and $625 \mathrm{ml}$, respectively. The human lung model proposed by Yeh and Schum (1980) was chosen for the simulations. The aerosol properties follow the results of measurements and are discussed in "Air quality observed during the study period" section. Table 1 summarizes the dataset used in the calculations. Despite using default values, it is important to note that accurate prediction of inhaled aerosols and their deposition into respiratory tract depend on a wide range of parameters as pointed by recent studies (e.g., Kim and $\mathrm{Hu}$ 2006; Finlay and Martin 2008).
Table 1 Parameters employed in the numerical simulations using MPPD

\begin{tabular}{ll}
\hline Species and model & \\
Species/geometry & Human Yeh/Schum Symmetric \\
FRC volume & $3,300.0 \mathrm{ml}$ \\
Head volume & $50.0 \mathrm{ml}$ \\
Breathing route & Nasal \\
Breathing parameters & \\
Tidal volume & $625.0 \mathrm{ml}$ \\
Breathing frequency & $12.0 \mathrm{~min}^{-1}$ \\
Inspiratory fraction & 0.5 \\
Pause fraction & 0.0 \\
Particle properties & \\
Diameter & Multiple diameters \\
Density & $1.0 \mathrm{~g} / \mathrm{cm}^{3}$ \\
Geometric standard deviation & $1.95 \mathrm{to} 2.18$ \\
Aerosol concentration & $1.0 \mu \mathrm{g} / \mathrm{m}^{3}$
\end{tabular}

In addition, there are still some gaps in the current knowledge on how ultrafine particles may cause adverse reactions (Kreyling et al. 2006).

\section{Results and discussion}

\section{Synoptic overview}

According to the National Centers for Environmental Prediction/National Center for Atmospheric Research global reanalysis data (Kalnay et al. 1996) and to the GOES-12 satellite infrared images (figures not shown), the weather between August 18 and 24, 2003 was marked by the presence of a low-level high-pressure system in the southeast region of Brazil. This system was associated with air mass subsidence, which inhibited cloud formation in São Paulo during that period. This is a typical synoptic condition for the austral winter season in São Paulo, favoring high pollutants concentration in the city. A cold front developed in the southern part of Brazil and quickly propagated to São Paulo State on August, 25, changing the conditions for pollutants dispersion at MASP. The hourly temperature, wind speed, and relative humidity time series seen in Fig. 1 were measured by an automatic surface data station located next to the experimental site.

Figure 1 shows the synoptic influence on the local weather situation. During the period between August 18 and 24 , wind speed was predominantly calm, with increasing temperatures and decreasing relative humidity. The passage of the cold front was approximately at 1200 coordinated universal time (UTC) on August 25. After that, both the mean and the daily temperature amplitude 
Fig. 1 Time series from Parque D. Pedro II automatic surface station data showing temperature $\left({ }^{\circ} \mathrm{C}\right)$, wind speed $\left(\mathrm{dm} \mathrm{s}^{-1}\right)$, and relative humidity (\%) from August 18 (0000 UTC) to September 2, 2003 (1200 UTC)

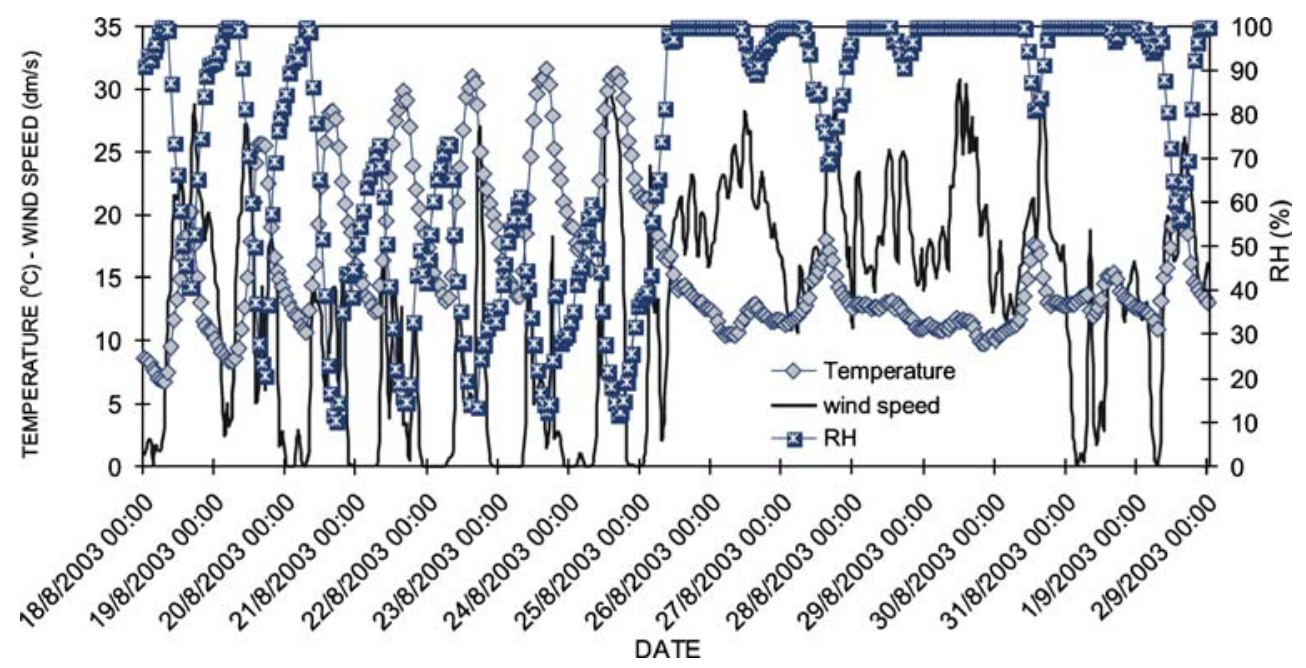

decreased. At the same time, the mean wind speed heightened. On August 26, the cold front was already in Rio de Janeiro (northeast from São Paulo). The high values of relative humidity in the postfrontal situation can be explained by the low-level circulation, which was dominated by southeastern winds blowing from the Atlantic Ocean. This wet wind circulation kept a low-level cloudiness sky during the following days, favoring the low concentration of pollutants.

Air quality observed during the study period

Figure 2 illustrates the behavior of $\mathrm{SO}_{2}, \mathrm{CO}, \mathrm{O}_{3}, \mathrm{NO}_{2}$, and $\mathrm{PM}_{10}$ concentrations observed at Parque D. Pedro II station (-23.54; -46.63). During the week of August 18 to 25, the average concentrations of $\mathrm{PM}_{10}$ seem to be very high, reaching an hourly mean of up to $283 \mu \mathrm{g} \mathrm{m}^{-3}$. In addition, the NAAQS of $150 \mu \mathrm{g} \mathrm{m}^{-3}$ (average on $24 \mathrm{~h}$ ) is exceeded during most of the polluted days of that week. On the other hand, in the following week, from August 26 to September 2 , the concentrations of pollutants considerably decrease when compared to the previous week and do not show any violation of the NAAQS. On this particularly clean week, the average $\mathrm{PM}_{10}$ in $24 \mathrm{~h}$ was $33 \mu \mathrm{g} \mathrm{m}^{-3}$, with hourly peaks not exceeding $60 \mathrm{\mu g} \mathrm{m}^{-3}$. Similar behaviors could be observed for the other pollutants. Therefore, during the second week studied, the air quality could be considered at an adequate level to protect human health from the potential effects of pollutants, according to NAAQS.

Aerosol size distributions

During the field experiment, aerosol size distributions for different weather conditions were measured and analyzed. Figure 3 shows the geometric mean diameter (GMD) and total particle concentration number ranging from 9.82 to $414 \mathrm{~nm}$. The diurnal cycle of the particle number concentration varied from 7,000 to $30,000 \mathrm{~cm}^{-3}$ during the polluted period (August 18-25), while varying from 1,300 to $13,000 \mathrm{~cm}^{-3}$ during the clean period (August 26 to September 2). Differently from polluted days, the clean period showed a regular maximum and minimum hourly mean concentration, with the minimum being observed at around 0500 hours and the maximum at around 0800 hours. Morning traffic is probably the responsible for the intense rate of particle number increase between 0500 and 0800 hours in the clean period.

The GMD shows a well-defined diurnal cycle under highly polluted conditions (Fig. 3). This contrasts with observations for particle concentrations, which do not show a regular diurnal cycle during the polluted week. Nevertheless, no regularity could be observed in the GMD behavior for the subsequent clean period in which the number of particles followed a well-defined diurnal cycle. Coagulation, transport, mixing, and water vapor condensation are possible mechanisms for the maintenance of diurnal cycles in the GMD. During the polluted period, growth rates of up to $5 \mathrm{~nm} \mathrm{~h}^{-1}$ in GMD can be observed at nighttime. According to cloud droplet activation mechanisms (see Pruppacher and Klett 1997), a particle of ammonium sulfate under high relative humidity can increase its diameter by two- or threefold when compared to dry conditions. As the GMD peaks observed in Fig. 4 coincide with maximum relative humidity, which is found around 0500 hours. It is expected that the observed diurnal cycle in GMD can be partially explained by the amount of water on the particles.

Hourly average number size distributions for three different times for both polluted and clean conditions are shown in Fig. 5. The values represent selected hourly averages: nighttime (0500 hours), morning (0800 hours), and afternoon (1700 hours). According to Fig. 5, under polluted conditions, particles are partitioned between Aitken and accumulation modes. Otherwise, clean period 
Fig. 2 Behavior of pollutants in Parque D. Pedro II station $(-23.54 ;-46.63)$ from August 18 to September 1, 2003. First panel time series for $\mathrm{SO}_{2}$ and CO. Second panel time series for $\mathrm{O}_{3}$ and $\mathrm{NO}_{2}$. Bottom panel time series for $\mathrm{PM}_{10}$. The line across the $P M_{10}$ time series indicates the 24-h NAAQS for this pollutant
Fig. 3 Hourly averages of geometric mean diameter of particles in the size range 9.82 $414 \mathrm{~nm}$ and particle number concentration
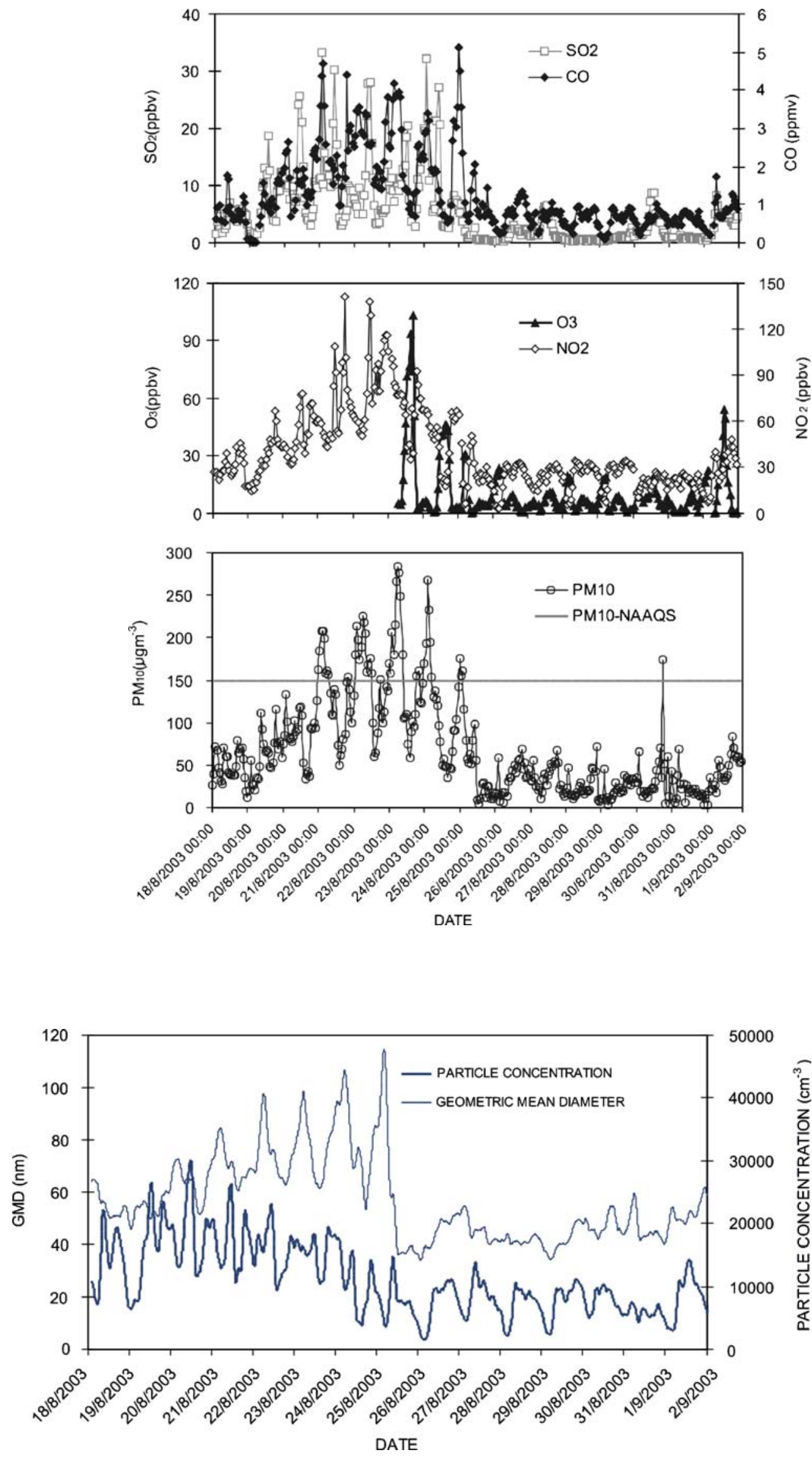
Fig. 4 Time series for geometric mean diameter and relative humidity from August 18 to September 2, 2003

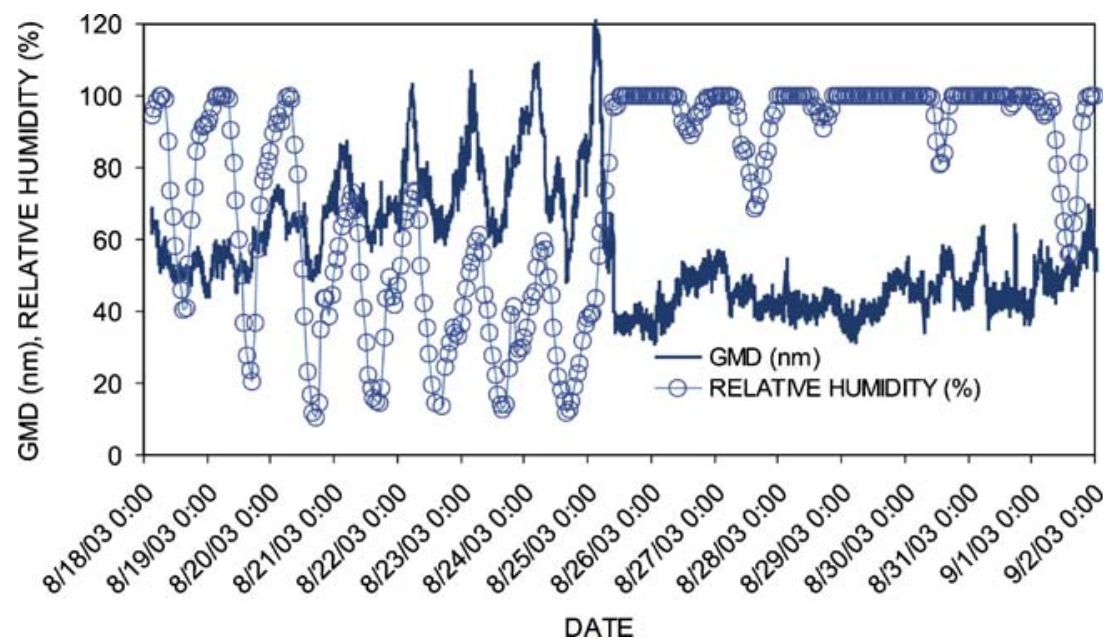

shows particles distributed in the nucleation and Aitken modes.

During the morning (0800 hours) and afternoon (1700 hours) of the polluted period, the traffic-related emissions have probably shifted the distribution toward the lower size ranges (GMD equals $95 \mathrm{~nm}$ for the morning and
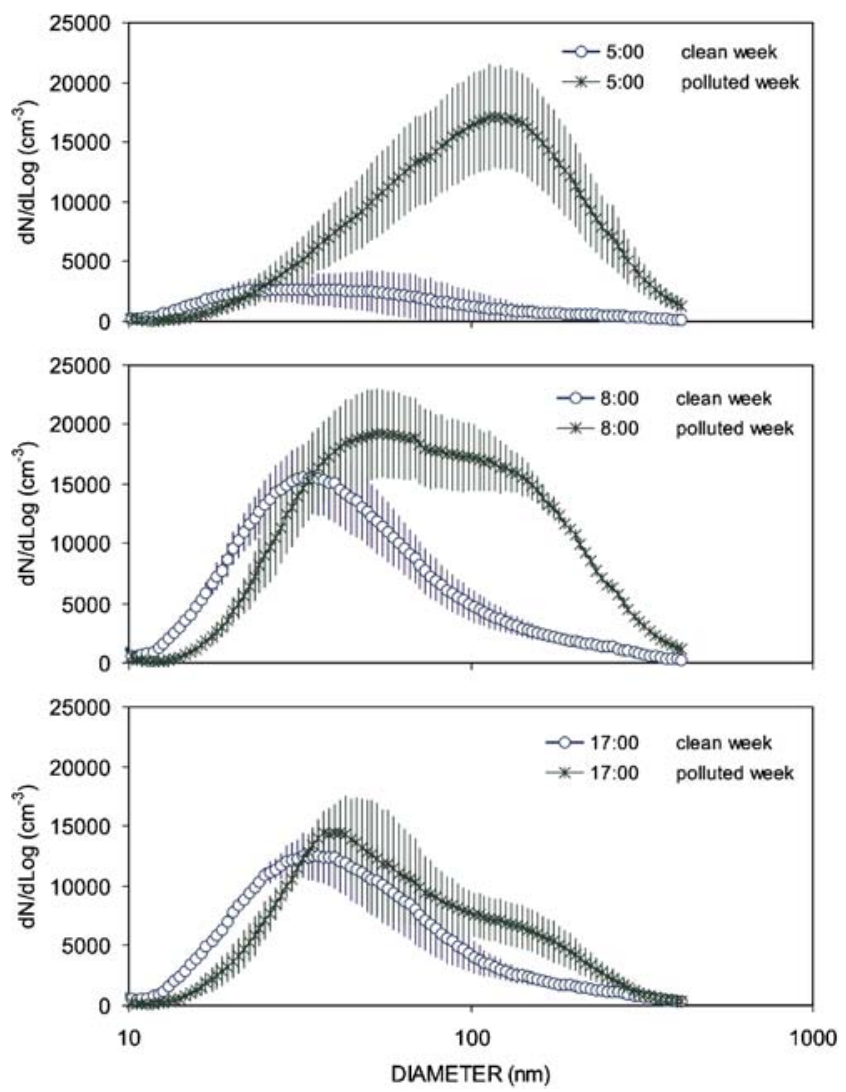

Fig. 5 Average particle number size distributions at polluted and clean periods for three different daily hours: nighttime (0500 hours), morning (0800 hours), and afternoon (1700 hours). The error bars indicate 1 standard deviation
$77 \mathrm{~nm}$ for the afternoon). The opposite can be observed during nighttime (0500 hours). In this case, it was hypothesized that water vapor condensation could be shifting the distribution toward large sizes (GMD of about $118 \mathrm{~nm}$ ), since it coincides with maximum relative humidity, as previously pointed out (Fig. 4). This concurrent shift in the size might also be partially caused by production of condensable compounds other than water vapor. However, both mechanisms fail to explain the simultaneously observed increase in concentration at nighttime and early morning hours during the polluted week. Two additional possible mechanisms can be suggested in order to explain the variation in number of particles. The first is during the night hours with the development of a shallow stable layer close to ground level. When the sun rises, the nocturnal layer starts to dissipate due to heating of the ground, and a mixing process promotes the dispersion of pollutants, reducing the concentration of particles. The second mechanism can be attributed to the continuous feeding on nucleation and Aitken modes by particles from traffic emission. However, nucleation and Aitken modes do not show significant change because particles could be removed from the accumulation mode by coagulation.

Guyon et al. (2005), using data from the Amazon region during biomass burning season, found GMD of $110 \pm 15 \mathrm{~nm}$ in 69 plumes within the boundary layer, a value very close to that observed during nontraffic-influenced hours of polluted week at MASP. Therefore, biomass burning smoke from local fires is a plausible mechanism to explain the occurrence of accumulation mode particles during the polluted period. According to forest fire monitoring provided by the National Institute of Space Research (http://www.cptec.inpe.br) using satellite data, the number of hot spots detected during the polluted week was more than 3,000 in South America. This number slightly decreased during the clean week, probably because of the 


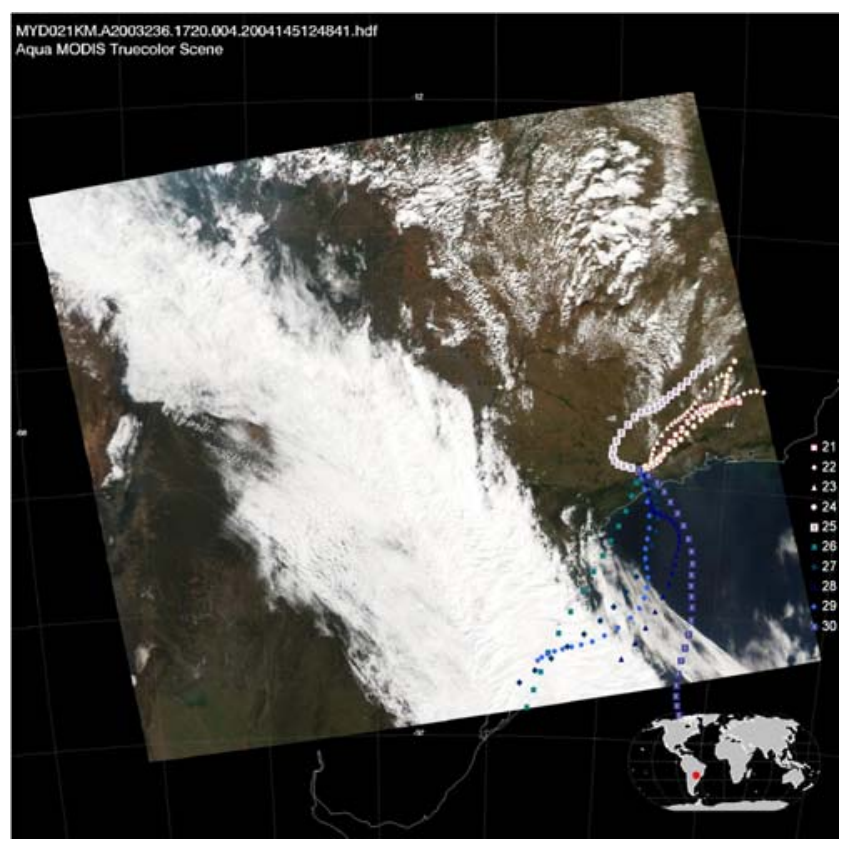

Fig. 6 Moderate-Resolution Imaging Spectroradiometer (MODISAQUA) image showing the South American southeastern region. The image was overlaid with back trajectories ending at 0000 UTC, 48-h duration, and produced with NOAA-HYSPLIT model (Draxler and Rolph 2003; Rolph 2003) available at http://www.arl.noaa.gov/ ready/. The right side numbers denote the corresponding back trajectories for polluted (August 21-25) and clean (August 26-30) periods. The cold frontal system that reached São Paulo on August 25 is shown covering the area from top left to lower right corner of the image. The image shows diffuse smoke plumes covering the northeast portion, while a few local plumes are seen blowing off Brazil's east coast on August 24, 2003 (http://modis-atmos.gsfc.nasa.gov)

prevailing rainfall, but continued high in some parts of South America. Figure 6 shows back trajectories for polluted and clean periods, indicating a complete opposite wind direction predominating for each period. In the first week of measurements, the wind blew predominantly from dry continental areas. From August 26, the wind direction changed and a maritime cool air mass predominated, pushing humidity toward the São Paulo area. The observed accumulated precipitation was $4.3 \mathrm{~mm}$ (August 25), $0.7 \mathrm{~mm}$ (August 26), $0.1 \mathrm{~mm}$ (August 27), $2.1 \mathrm{~mm}$ (August 28), $0.9 \mathrm{~mm}$ (August 29), and $2.2 \mathrm{~mm}$ (August 31).

The number size distribution in the polluted week was shown to be broader than in the clean week. This reduces the differences between spectral peak values associated to each type of distribution. In addition, the broadening or narrowing of the distribution reflects the impact of processes which depend on atmospheric conditions and size in the formation of particles. These processes will define the predominance of each mode. The observed mean concentration of particles for the polluted week was 13,520, 18,350 , and $10,670 \mathrm{~cm}^{-3}$ at 0500,0800 , and 1700 hours, respectively.
Under clean atmospheric conditions, the GMD predominates at around $56 \mathrm{~nm}$ at any given time. The most significant difference observed under these conditions occurs between daytime and nighttime for the particle concentrations. In this case, traffic is the only significant source of particles, causing high concentrations of particles only during daytime. The observed mean concentration of particles for the clean week was 2,470, 11,080, and $9,340 \mathrm{~cm}^{-3}$ at 0500,0800 , and 1700 hours, respectively.

It has been recognized that clean atmospheric conditions favor the nucleation of new particles. On the other hand, due to condensation of vapors, polluted atmosphere inhibits the nucleation and promotes the growth of existing particles. As a result, clean atmospheric condition shows higher concentrations of nucleation mode particles than the polluted one. Nucleation has long been known to be a process that results in UFP formation in the atmosphere. The vapor compounds in the atmosphere promoting nucleation of new particles are sulfuric acid, nitric acid, and organic matter. Nucleation events have been reported in several different environments, from high-polluted areas to remote regions where pristine atmospheric conditions predominate (Birmili and Wiedensohler 1998; Park et al. 2004; Stanier et al. 2004). Fresh nucleated particles can continue to grow by condensation of low volatile vapors and can also be removed by coagulation in such a way that nucleation mode quickly disappears. Although there are no appropriate measurements to confirm the occurrence of nucleation, the process cannot be disregarded. Meteorological parameters such as low temperatures and high relative humidity are thought to favor the formation of new particles.

\section{Potential UFP health effects: a modeling evaluation}

In order to assess the potential health effects caused by UFP, a mathematical modeling evaluation of particle size distributions under different pollution levels was considered. The distributions associated with the three previously analyzed daily hours were modeled using MPPD model. The potential impacts for each period were evaluated through the fraction of ambient inhalant particles deposited in each human respiratory tract region: head or upper respiratory tract (HEAD), tracheobronchial area (TB), and alveolar or pulmonary area (P). The fraction of deposited particles as a function of the conducting airway generations is shown in Fig. 7a. The curves show the least (0500 hours-polluted) and most (0800 hoursclean) efficiently deposited size distributions. The other selected distributions stay between the two curves, as illustrated in Fig. 7a. The most significant differences are observed in alveolar region, which include the last 12 respiratory airway generations for humans. 
Fig. 7 Deposition of inhaled particles in human tracheobronchial and alveolar region showing deposited fraction (a) and deposited fraction per unit area (b) per airway generation, according to MPPD prediction
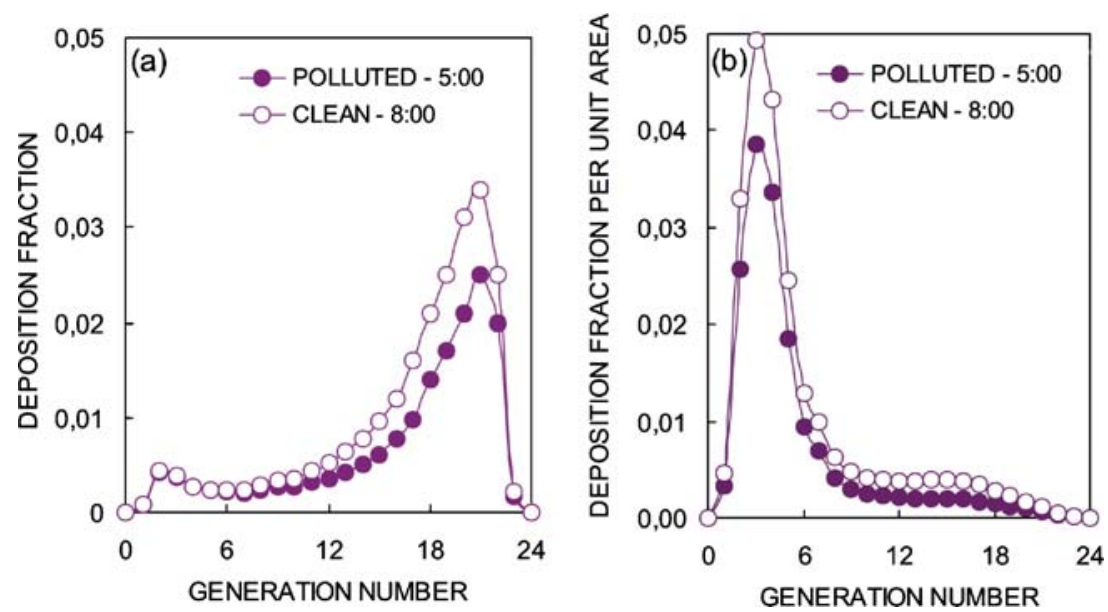

According to Fig. 7a, the model predicts that the inhaled particles have their highest deposition efficiency in the alveolar region. On the other hand, a high deposition fraction in a region of the respiratory tract does not necessarily correspond to a high dose which can be delivered to individual cells in that region, as there are large differences in the epithelial surface area among regions (Hofmann et al. 2002). For example, the epithelial surface areas in tracheobronchial and alveolar regions differ greatly. The alveolar epithelial surface area within an average adult human lung has been estimated to be as large as $150 \mathrm{~m}^{2}$. Therefore, expressing the deposition data normalized per unit surface area (Fig. 7b) shows that the upper generations of the tracheobronchial region receives higher doses per unit surface area than the alveolar region.

The deposition fractions, normalized by the total of particles at each selected daily hour for all three regions of the respiratory tract, are shown in Fig. 8. The fraction of deposited particles increases from the nasal to the alveolar region in both weeks. As previously discussed, the deposited amount per unit surface area shows an opposite signal, with the $\mathrm{TB}$ region receiving higher deposition per unit area than the $\mathrm{P}$ region. The predicted values suggested that during nighttime (0500 hours), under clean conditions, there is no significant fraction of particles being deposited in the respiratory tract. However, during daytime (0800 hours; 1700 hours), the particle deposition in clean conditions cannot be neglected. In the afternoon measurement hours of the clean week (1700 hours), the deposition fraction can be even larger than that of the polluted week, both in TB and $\mathrm{P}$ regions. This is a scenario which is completely impossible to be revealed using the traditional $\mathrm{PM}_{10}$ (or even $\mathrm{PM}_{2.5}$ ) measurements as indicators of the level of health risk caused by particles. At 0800 hours, for example, $\mathrm{PM}_{10}$ shows values that can be more than tenfold larger for the polluted week when compared to the clean one.

In the atmospheric scenario described above, clean atmospheric conditions prevailed during the second week. Background aerosols might not be present in the ambient air, since light rain predominated. Thus, primary aerosols emitted from vehicular sources dominated the aerosol size distributions. In addition, during late nighttime, the vehicular source contribution is practically null, which explains the very low deposition rate at 0500 hours.
Fig. 8 Deposited particles fraction in human HEAD, TB, and $\mathrm{P}$ respiratory tract regions predicted by MPPD model for three distinct daily hours under polluted and clean conditions
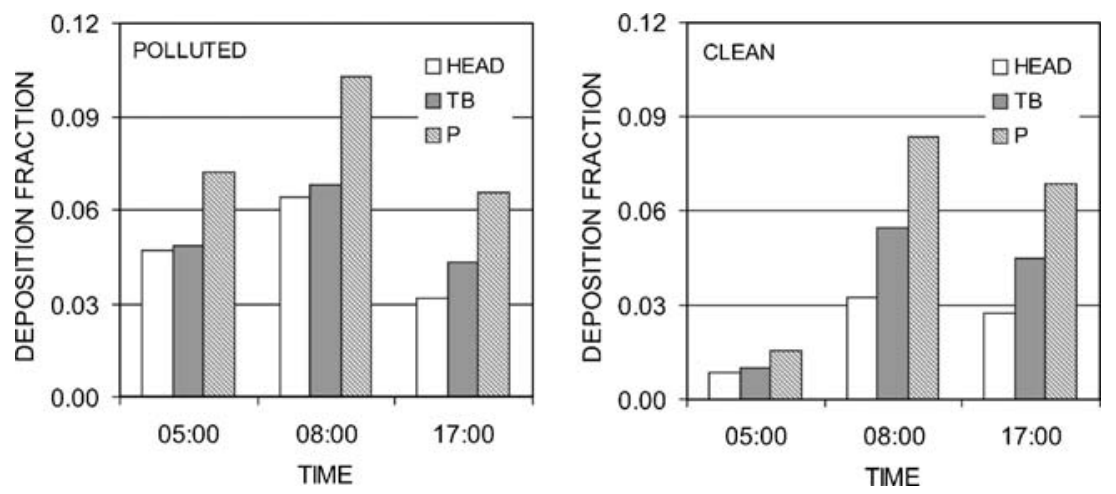
The main deposition mechanism of inhaled UFP in the respiratory tract is Brownian diffusion. Based on this assumption, it is expected that the fractional deposition of inhaled particles predicted by MPPD model provides values which would increase with the decreasing size of particles. The different deposition probabilities have consequences for types of inhaled particles of different sizes. For instance, according to Fig. 9, a size distribution characterizing the clean period ( 0800 hours) is efficiently deposited since its GMD $(43 \mathrm{~nm})$ is benefited by Brownian diffusion. On the other hand, particles characterizing the polluted period (0500 hours) are less efficiently deposited because they are associated with large GMD (96 nm). Note that the selected hourly averages correspond to the peaks in $\mathrm{PM}_{10}$ and number concentration for polluted (0500 hours) and clean weeks (0800 hours), respectively. In the comparative example, the particle concentration under polluted conditions is about $22 \%$ greater than the clean one.

Another important feature to be considered is related to the surface area per unit mass of particles. As a particle decreases in size, its surface area per mass unit increases and a greater proportion of atoms/molecules are found at the surface of particles compared to those inside. The surface number of molecules increases exponentially when particle size decreases, reflecting the importance of surface area. Since biological effects can be associated with the number of exposed molecules in the particle surface (Oberdörster et al. 2005a, b), as the particles decrease in size, we can expect an increase in chemical and biological activity, mainly associated to UFP.

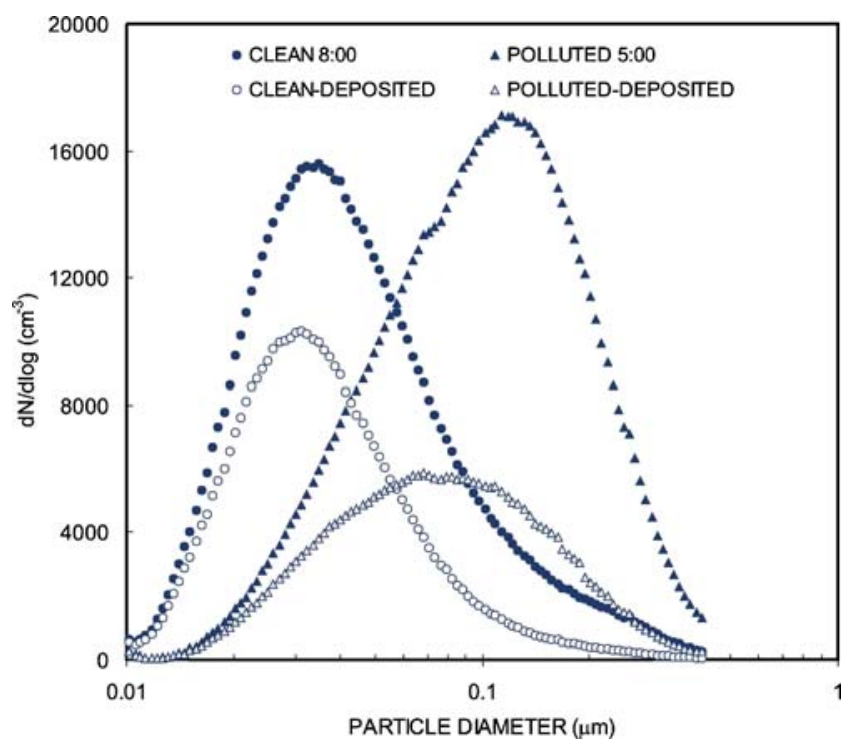

Fig. 9 Measured and deposited size distributions for two distinct daily hours under polluted and clean conditions

\section{Remarks and conclusions}

Results concerning the first measurements involving diurnal variation of the aerosol number size distribution $(9.82$ $414 \mathrm{~nm}$ ) in the highly polluted megacity of São Paulo were presented. Two weeks were analyzed, being one polluted and the other one clean, showing completely distinct behavior for both GMD and total number concentration. The diurnal cycle of traffic was found to govern the total particle number concentration during the entire period of clean days. During the polluted period, a nontraffic source could contribute to drive the concentration variability, possibly, biomass burning.

The aerosol size distributions were found to be broader during the polluted period than during the clean one. The modal diameters of the size spectra during the polluted period were about twice as large as those during the clean period. A partial disappearance of small particles when high concentrations of larger particles were present could be observed. Larger particles cannot only be used as a sink for coagulation of small particles but also for their vapor precursors. This behavior raises an important issue on the establishment of regulation standards, especially if the concentration of UFP is supposed to be controlled on a number basis. With the eventual intention of reducing the resultant UFP concentrations, should the vapor precursors be controlled at the source? Although not extensively studied yet, as pointed out by Biswas and $\mathrm{Wu}$ (2005), this is an important issue to be discussed in the context of establishing new standards.

Applying a pulmonary health effect parameterization on the particle number distribution, the results show a more significant effect associated to the smaller particles. The results also suggest that the period characterized as clean, based on $\mathrm{PM}_{10}$ measurements, cannot be considered a period presenting low health impacts, when using UFP concentration as criteria. In this context, more extensive studies could be useful for the assessment of the potential risk of inhaling very small particles that could be predominant during clean periods. In addition, the chemical composition of particles is also very important, since health effects can depend on chemical and catalytic properties, as suggested by Limbach et al. (2007). Parameters describing the time-dependent dissolution and absorption in blood can vary in several degrees of magnitude, from materials that are readily absorbed by the blood to relatively insoluble materials (ICRP 2006). It is also important to recognize that materials with different physical, chemical, and biological properties may be positioned in different ranges of the size distribution and cause different effects (e.g., Kreyling et al. 2006; Longest and Xi 2008). This nonlinearity, inherent to the behavior of particles, definitively renders the particle mass incomplete as a reference to the regulation of air quality. 
Some important features concerning the results of this work should be highlighted. The first one is related to the total UFP mass that can be deposited in the human respiratory tract. As showed by Kittelson et al. (2001), concentrations as high as $10^{7} \mathrm{~cm}^{-3}$ may be observed near curbsides of roads. The UFP concentrations were lower at a short distance from the highways. However, car passengers on the highways are directly exposed to these higher concentrations. The second one is that UFP are very short-lived and disappear through coagulation within a short time. Nevertheless, it is important to recognize that they are continuously generated by a source (vehicular) and the diurnal cycle is very well defined. Finally, the health consequences of UFP inhalation have arisen as an important area of investigation. As pointed out by Oberdörster and Utell (2002), we should be more cautious when introducing new technologies based on the assumption that they would result in cleaner air with fewer and less toxic contaminants without an adequate understanding of potential associated toxicity. Therefore, the collaboration among technology developers, epidemiologists, and toxicologists is fundamental in this field.

Acknowledgments The authors would like to thank the Companhia de Tecnologia de Saneamento Ambiental (CETESB) and the Physics Institute (University of São Paulo) for providing the air quality surface data used in this research. Appreciation is given to the Mackenzie University for providing the sampling site and infrastructure conditions for the measurements. The multiple path particle dosimetry model (MPPD) was developed by the Chemical Industry Institute of Toxicology (CIIT), USA in collaboration with National Institute of Public Health and Environment (RIVM) from The Netherlands. The authors would also like to thank both institutes for providing the use of the model. The authors also acknowledge the NOAA Air Resources Laboratory (ARL) for the provision of the HYSPLIT transport and dispersion model used in this publication (http://www.arl.noaa.gov/ready.html). This work was carried out with the aid of a grant from the Inter-American Institute for Global Change Research (IAI) CRN II 2017 which is supported by the US National Science Foundation (Grant GEO-0452325).

Open Access This article is distributed under the terms of the Creative Commons Attribution Noncommercial License which permits any noncommercial use, distribution, and reproduction in any medium, provided the original author(s) and source are credited.

\section{References}

Anjilvel S, Asgharian B (1995) A multiple-path model of particle deposition in the rat lung. Fundam Appl Toxicol 28:41-50

Asgharian B, Price OT (2007) Deposition of ultrafine (nano) particles in the human lung. Inhal Toxicol 19:1045-1052

Asgharian B, Hofmann W, Bergmann R (2001a) Particle deposition in a multiple-path model of the human lung. Aerosol Sci Technol 34:332-339. doi:10.1080/02786820119122

Asgharian B, Hofmann W, Miller FJ (2001b) Mucociliary clearance of insoluble particles from the tracheobronchial airways of the human lung. J Aerosol Sci 32:817-832. doi:10.1016/S0021-8502 (00)00121-X
Asgharian B, Price OT, Hofmann W (2006) Prediction of particle deposition in the human lung using realistic models of lung ventilation. J Aerosol Sci 37:1209-1221. doi:10.1016/j.jaero sci.2006.01.002

Baldauf R, Watkins N, Heist D, Bailey C, Rowley P, Shores R (2009) Near-road air quality monitoring: factors affecting network design and interpretation of data. Air Qual Atmos Health 2:1-9. doi:10.1007/s11869-009-0028-0

Birmili W, Wiedensohler A (1998) The influence of meteorological parameters on ultrafine particle production at a continental site. $\mathrm{J}$ Aerosol Sci 29:S1015-S1016

Biswas P, Wu C (2005) Nanoparticles and the environment. J Air Waste Manage Assoc 55:708-746. doi:10.1023/A:1021618607970

CETESB (2004) Relatório de qualidade do ar no Estado de São Paulo 2003, São Paulo, 140p [in Portuguese]. Available via DIALOG http://www.cetesb.sp.gov.br/Ar/publicacoes.asp

Cheng CS, Campbell M, Li Q, Li G, Auld H, Day N, Pengelly D, Gingrich S, Klaassen J, MacIver D, Comer N, Mao Y, Thompson W, Lin H (2009) Differential and combined impacts of extreme temperatures and air pollution on human mortality in southcentral Canada. Part I: historical analysis. Air Qual Atmos Health 1:209-222. doi:10.1007/s11869-009-0027-1

Choi JI, Kim CS (2007) Mathematical analysis of particle deposition in human lungs: an improved single path transport model. Inhal Toxicol 19:925-939. doi:10.1080/08958370701513014

Conceição GM, Miraglia SG, Kishi HS, Saldiva PH, Singer JM (2001) Air pollution and child mortality: a time series study in São Paulo, Brazil. Environ Health Perspect 109:347-350

Donaldson K, Stone V, Clouter A, Renwick L, MacNee W (2001) Ultrafine particles. Occup Environ Med 58:211-216. doi:10.1136/oem.58.3.211

Draxler RR, Rolph GD (2003) HYSPLIT (Hybrid Single-Particle Lagrangian Integrated Trajectory) Model access via NOAA ARL READY Website (http://www.arl.noaa.gov/ready/hysplit4.html). NOAA Air Resources Laboratory, Silver Spring, MD

Farhat SCL, Paulo RLP, Shimoda TM et al (2005) Effect of air pollution on pediatric respiratory emergency room visits and hospital admissions. Braz J Med Biol Res 38:227-235

Finlay WH, Martin AR (2008) Recent advances in predictive understanding of respiratory tract deposition. J Aerosol Med 21:1-7

Frank BP, Tang S, Lanni T et al (2007) The effect of fuel type and aftertreatment method on ultrafine particle emissions from a heavy-duty diesel engine. Aerosol Sci Technol 41:1029-1039. doi:10.1080/02786820701697531

Freijer JI, Cassee FR, Subramaniam R et al (1999) Multiple path particle deposition model (MPPDep version 1.11): a model for human and rat airway particle deposition. RIVM Publication 650010019

Guyon P, Frank G, Welling M et al (2005) Airborne measurements of trace gas and aerosol particle emissions from biomass burning in Amazonia. Atmos Chem Phys 5:2989-3002

Hofmann W, Asgharian B, Winkler-Heil R (2002) Modeling intersubject variability of particle deposition in human lungs. J Aerosol Sci 33:219-235. doi:10.1016/S0021-8502(01)00167-7

Holberg CJ, O'rourke MK, Lebowitz MD (1987) Multivariate analysis of ambient environmental factors and respiratory effects. Int $\mathrm{J}$ Epidemiol 16:399-410

ICRP (2006) Draft Recommendations of the International Commission on Radiological Protection. ICRP publications on line accessed: http:// www.icrp.org/docs/ICRP Recs 0227606 web cons 5 June.pdf

James AC, Stahlhofen W, Rudolf $G$ et al (1994) International Commission on Radiological Protection (ICRP). Annexe D: deposition of inhaled particles. In: Human respiratory tract model for radiological protection. ICRP Publication 66. Ann 24:1-300

Kalnay E, Kanamitsu M, Kistler R et al (1996) The NCEP/NCAR 40year reanalysis project. Bull Amer Meteor Soc 77:437-471. doi:10.1175/1520-0477(1996) 077\&lt;0437:TNYRP\&gt;2.0.CO;2 
Kittelson DB, Watts JJ, Johnson RJ (2001) Fine particle (nanoparticle) emissions on Minnesota highways. Final report, May 2001. Minnesota Department of Transportation, St. Paul

Kim CS, Hu SC (2006) Total respiratory tract deposition of fine micrometer-sized particles in healthy adults: empirical equations for sex and breathing pattern. J Appl Physiol 101:401-412. doi:10.1152/japplphysiol.00026.2006

Kreyling WG, Semmler-Behnke M, Moller W (2006) Ultrafine particle-lung interactions: does size matter? J Aerosol Med 19:74-83

Laakso L, Hussein T, Aarnio P et al (2003) Diurnal and annual characteristics of particle mass and number concentrations in urban, rural and Arctic environments in Finland. Atmos Environ 37:2629-2641. doi:10.1016/S1352-2310(03)00206-1

Limbach LK, Wick P, Manser P et al (2007) Exposure of engineered nanoparticles to human lung epithelial cells: influence of chemical composition and catalytic activity on oxidative stress. Environ Sci Technol 41:4158-4163. doi:10.1021/es062629t

Longest PW, Xi J (2008) Condensational growth may contribute to the enhanced deposition of cigarette smoke particles in the upper respiratory tract. Aerosol Sci Tech 42:579-602. doi:10.1080/ 02786820802232964

Martins LD, Andrade MF, Freitas ED et al (2006) Emissions factors for gas-powered vehicles traveling through road tunnels in São Paulo, Brazil. Environ Sci Technol 40:6722-6729. doi:10.1021/ es052441u

Nazridoust K, Asgharian B (2008) Unsteady-state airflow and particle deposition in a three-generation human lung geometry. Inhal Toxicol 20:595-610. doi:10.1080/08958370801939374

Oberdörster G, Utell MJ (2002) Ultrafine particles in the urban air: to the respiratory tract - and beyond? Environ Health Perspect 110: A440-A441

Oberdörster G, Maynard A, Donaldson K et al (2005a) Principles for characterizing the potential human health effects from exposure to nanomaterials: elements of a screening strategy. Part Fibre Toxicol 2:1-35. doi:10.1186/1743-8977-2-8

Oberdörster G, Oberdörster E, Oberdörster J (2005b) Nanotoxicology: an emerging discipline evolving from studies of ultrafine particles. Environ Health Perspect 113:823-839. doi:10.1289/ehp.7339

Ostiguy C, Lapointe G, Ménard L et al (2006) Health effects of nanoparticles. Report IRSST R-469, Montréal

Park J, Sakurai H, Vollmers K et al (2004) Aerosol size distributions measured at the South Pole during ISCAT. Atmos Environ 38:5493-5500. doi:10.1016/j.atmosenv.2002.12.001
Price OT, Asgharian B, Miller FJ et al (2002) Multiple Path Particle Dosimetry Model (MPPD v 1.0): a model for human and rat airway particle dosimetry. RIVA report 650010030, National Institute for Public Health and the Environment (RIVM), Bilthoven, The Netherlands

Pruppacher HR, Klett JD (1997) Microphysics of clouds and precipitation. Kluwer Academic, Dordrecht

Ristovski ZD, Jayaratne ER, Lim M et al (2006) Influence of diesel fuel sulfur on nanoparticle emissions from city buses. Environ Sci Technol 40:1314-1320. doi:10.1021/es050094i

Rolph GD (2003) Real-time Environmental Applications and Display System (READY) website (http://www.arl.noaa.gov/ready/hysplit4. $\mathrm{html}$ ). NOAA Air Resources Laboratory, Silver Spring, MD

Semmler-Behnke M, Takenaka S, Fertsch S et al (2007) Efficient elimination of inhaled nanoparticles from the alveolar region: evidence for interstitial uptake and subsequent reentrainment onto airways epithelium. Environ Health Perspect 115:728-733. doi: $10.1289 /$ ehp. 9685

Sioutas C, Delfino RJ, Manisha S (2005) Exposure assessment for atmospheric ultrafine particles (UFPs) and implications in epidemiologic research. Environ Health Perspect 113:947-955. doi:10.1289/ehp.7939

Stanier CO, Khlystov AY, Pandis SN (2004) Ambient aerosol size distributions and number concentrations measured during the Pittsburgh Air Quality Study (PAQS). Atmos Environ 38:32753284. doi:10.1016/j.atmosenv.2004.03.020

U.S. Environmental Protection Agency (2007) Review of the national ambient air quality standards for ozone: policy assessment of scientific and technical information. Staff Paper Available via DIALOG http://www.epa.gov/ttn/naaqs/standards/ozone/data/ 2007_01_ozone_staff_paper.pdf

Winter-Sorkina R, Cassee FR (2002) From concentration to dose: factors influencing airborne particulate matter deposition in humans and rats. Report 650010031. National Institute of Public Health and the Environment (RIVM), Bilthoven, The Netherlands

Yeh HC, Schum GM (1980) Models of human lung airways and their application to inhaled particle deposition. Bull Math Biol 42:461-480. doi:10.1007/BF02460796

Ynoue RY, Andrade MF (2004) Size-resolved mass balance of aerosol particles over the São Paulo metropolitan area of Brazil. Aerosol Sci Technol 38:52-62

Zhang Q, Streets DG, He K, Klimont Z (2007) Major components of China's anthropogenic primary particulate emissions. Environ Res Lett 2:045027. doi:10.1088/1748-9326/2/4/045027 